\title{
Open Innovation Process for Inter-Organizational Projects
}

\author{
Susanne $\operatorname{Marx}^{1,2^{*}}$ \\ ${ }^{1}$ Faculty of Business Studies, Stralsund University of Applied Sciences, \\ Zur Schwedenschanze 15, 18435 Stralsund, Germany \\ ${ }^{2}$ Faculty of Computer Science and Electrical Engineering, University of Rostock, \\ Albert-Einstein-Str. 22, 18059 Rostock, Germany \\ susanne.marx@hochschule-stralsund.de
}

\begin{abstract}
Open Innovation (OI) research has covered various organizational forms in dimensions of durability (permanent versus temporary organizing) and organizational scope (intra- or inter-organizational). Inter-organizational forms both temporary and permanent - are regarded mainly as modes of OI. However, these organizational forms also act as initiators of OI activities to extend knowledge transfer across the inter-organizational consortium borders, which is hardly researched. To address this gap, the research presented in this article develops an OI process for inter-organizational projects (IOP) as initiators of OI. The initial model is developed by action research with an IOP of museums and educational institutions implementing a series of hackathons. The model's applicability is then evaluated for other IOPs by a survey, indicating the model's suitability for practitioners. Findings point to the importance of collaborative activities for aligning the OI initiative with both individual partners' and common project goals, while outbound activities are regarded as least important despite the time-limitation of the project. The research is limited by its focus on the specific IOP environment of EU-funded projects and the small scope of the survey.
\end{abstract}

Keywords: Open Innovation, Inter-Organizational Project, Innovation Process.

\section{Introduction}

The paradigm of Open Innovation (OI) has seen strong growth in research in the past decade, with a prevailing focus on the focal firm [1], [2]. Despite the research attention, West and Bogers [3] urge the enhancement of understanding from additional perspectives, e.g., network forms of collaboration, and other industry types, e.g., not-for-profit, which has inspired the present research.

Chesbrough and Bogers [4] suggest various organizational perspectives for researching OI. The present research approaches these by the dimensions of durability (permanent versus temporary) and scope (intra- versus inter-organizational). While OI initiatives by definition cross organizations' borders, the perspective of research mainly focuses on the focal firm as the entity

\footnotetext{
* Corresponding author

(C) 2021 Susanne Marx. This is an open access article licensed under the Creative Commons Attribution License (http://creativecommons.org/licenses/by/4.0).

Reference: S. Marx, "Open Innovation Process for Inter-Organizational Projects," Complex Systems Informatics and Modeling Quarterly, CSIMQ, no. 29, pp. 36-52, 2021. Available: https://doi.org/10.7250/csimq.2021-29.03

Additional information. Author's ORCID iD: S. Marx - orcid.org/0000-0003-3294-5351. PII S225599222100165X. Received: 9 December 2021. Accepted: 22 December 2021. Available online: 31 December 2021.
} 
to initiate or partake in OI activities [1], thus, the permanent, intra-organizational perspective on OI. The temporary perspective of organizing from an intra-organizational view, focuses on the implementation of OI projects and their management needs, yet, mainly from the initiating firm's viewpoint, e.g., linking project management research to OI [5], [6].

Inter-organizational structures constitute a very large part of the wide spectrum of the modes of OI, by which a focal organization can commence its innovation process. OI in networks or clusters, as the permanent form, has specifically attracted research attention [7]-[11]. However, temporary, inter-organizational projects (IOPs) are an increasingly common form of organizing [12], [13]. From an OI perspective, this form of organizing contains both the challenges of interorganizational work (e.g., equivocality [14], or differences in practices [15]) and of projects (limitation of time, budget, scope [16]). IOPs are researched as modes of OI [14], [17]-[19]. However, although research into how IOPs themselves initiate OI is recommended, it has scarcely been undertaken as yet [20].

Since OI, by its definition, focuses on a process view [4], this research sets out to design a process for managing OI initiated by IOPs. It informs both theory on the perceived importance of OI activities in IOPs and serves IOP managers with a tried and evaluated model. The article follows the Design Science Research paradigm towards developing the process model, combining research methods of action research, interviews, and survey data. The action research cycle is implemented with an IOP of not-for-profit organizations such as museums, educational institutions, and non-governmental organizations (NGOs), funded by a European Interreg program. The article first provides the theoretical framework, then displays the research results along the Design Science Research process, leading towards discussing the suggested process model.

\section{Background}

\subsection{Open Innovation}

Chesbrough and Bogers [4, p. 17] define Open Innovation (OI) "as a distributed innovation process based on purposively managed knowledge flows across organizational boundaries, using pecuniary and non-pecuniary mechanisms in line with the organization's business model". The approach can support both outside-in knowledge flows (e.g., idea competition) or inside-out flows (e.g., joint venture) [21]. Gassmann and Enkel also identify a coupled innovation process [22], focusing on collaboration. Piller and West [23, p. 39] extend this understanding of "coupled open innovation as an interactive, collaborative process of joint value creation" with various actors involved (e.g., users, universities) in different modes (extending to networks or other interorganizational settings). For enabling organizations to establish OI practices, Zynga et al. [24, p. 18] suggest that micro-foundations are needed consisting of "individuals, processes and structures". The aspect of organizational structures serves as one perspective on extant OI research.

\subsection{Open Innovation: An Organizational Perspective}

The first dimension to distinguish organizational structures is durability, specifying permanent versus temporary organizing [25], [26]. The second dimension is the organizational scope of organizing with intra-organizational versus inter-organizational links [2], which Teece [27] associates with facilitating the innovation process. Four different organizational perspectives result for analyzing OI (Table 1).

The intra-organizational view distinguishes between perspectives of the focal firm, as the permanent organization, and a project, as a temporary organization. The analysis of the permanent organization prevails in OI research, focusing on the focal firm that initiates or partakes in OI [1], [2], [28]. There is not much research about the temporary organization form [29], in particular when used in the intra-organizational scope [4]. Research investigates the role 
of projects as means to realize OI; the presence of various projects seems to indicate the process of building the OI capability of the firm [6], [30].

Table 1. Organizational perspectives on OI

\begin{tabular}{|l|l|l|}
\hline Organizational scope & Permanent & Temporary \\
\hline Intra-organizational & $\begin{array}{l}\text { I Permanent organization } \\
\bullet \text { initiating OI across firm boundaries, e.g., } \\
{[1], \text { [23], [31]-[33] }}\end{array}$ & $\begin{array}{l}\text { II Firm-governed project } \\
\bullet \text { form of OI, e.g., [5], [6] }\end{array}$ \\
\hline Inter-organizational & $\begin{array}{l}\text { III Network organization } \\
\bullet \text { form of OI, e.g., [2], [7], [9]-[11] } \\
\text { initiating OI across consortium } \\
\text { boundaries, e.g., [28] }\end{array}$ & $\begin{array}{l}\text { IV Inter-organizational project } \\
\bullet \text { form of OI, e.g., [14], [17]-[19] } \\
\text { initiating OI across consortium } \\
\text { boundaries, e.g., [20] }\end{array}$ \\
\hline
\end{tabular}

Innovation focus shifts from "firm-centric to network-centric innovation" [34, p. 40] for reasons of efficiency, learning, shared risk-taking, and optimized knowledge flows [35]. The inter-organizational perspective focuses on permanent structures such as networks or alliances [4] or temporary organizational forms such as inter-organizational projects [13]. Network organizations consist of several independent organizations that maintain continuous and repeated relations across organizational boundaries [36]. Research on innovation related to networks mainly addresses innovation within the network or inter-organizational relations, seeing the network as a mode of OI [7], [9]-[11]. DeFillippi and Sydow [15] argue that working across organizational borders raises tensions that need to be managed. One of these is the balance between using established practices and creating new ones [15, p. 11], the so-called "difference paradox". Sydow and Müller-Seitz [28] suggest the notion of "stretching practice" to transfer a known practice to an uncertain and new context for OI in networks. They argue that further understanding is needed about OI, involving knowledge even outside the network boundaries, thus the network itself initiating OI.

Inter-organizational projects [13] or inter-firm projects [12] are temporary inter-organizational activities. Jones and Lichtenstein [37, p. 234] define them thus: "Inter-organizational projects involve two or more organizational actors from distinct organizations working jointly to create a tangible product/service in a limited time." Thus, inter-organizational projects provide the tensions caused by working across organizations and add time, scope, and budget limitation as a characteristic of projects [16]. For instance, time limitation might affect OI in such projects since implementing OI methods requires learning time [38]. Inter-organizational projects, themselves, are mainly researched as a mode of OI [14], [17]-[19]. Du et al. [18] argue for the adaptation of OI implementation, e.g., PM formality to enhance OI success. One reason could be the diverging perceptions of partners, which Eriksson et al. [14, p. 691] call equivocality and conclude that "equivocality, or divergent interpretations and understandings of tasks and knowledge, has negative effects on performance because it increases conflicts and creates communication and coordination challenges in inter-organizational innovation projects." Barbosa et al. [17] argue that an OI project needs a specific project methodology to cope with partners' differences and the higher uncertainty in inter-organizational collaboration projects [17]. However, research shows that even in an inter-organizational project, OI activities are initiated to acquire knowledge outside the project boundaries [20]. The tasks in temporary organizations are unique and not repetitive [25]. To fulfil the unique task of implementing OI in an IOP thus implies the need for a tailored process.

\subsection{Open Innovation: A Process Perspective}

Open innovation describes OI as an innovation process to be actively managed [4]. Various suggestions describe the innovation process in general [21], [35], [39]-[42]. The process concepts are united by the understanding that they are a sequence of activities to be managed. 
One approach considers a Stage-Gate model of sequenced phases [41] developed for new product development projects. Various stage-gate models are suggested for inbound and outbound knowledge exchange [32], [43]. Some of these only distinguish the front end of innovation (ideation and selection) and the back end of innovation (implementation) [21]. West and Bogers [44] suggest three linear stages (obtaining, integrating, commercializing) amended by collaboration (interaction) as a continuous activity. The Stage-Gate process has been modified to suit an Open Innovation approach [32], [41] since a tailored innovation process, specific both to the organization and the challenge faced, is recommended [45]. Bican et al. [46] take a broader view on the lifecycle of OI, arguing that earlier work had primarily concentrated on the operation phase of OI and they add two more phases: preparation and termination. Having such a specific process for managing open innovation is found to be supportive [24], [47], [48] since unknown and unclear processes are identified as problems for implementing Open Innovation [47]. Roberts et al. [48, p. 122] argue that "formalization helps to codify best practices", and Lakemond et al. [31, p. 345] see that the greater the number of partners that are involved in an OI initiative, the greater is the need for project management practices to "align and control partners". Guertler and Sick [5] find that project management helps make OI concepts actionable by coordinating actions and interests and implementing rules and routines. Such detailed activities or implementing routines, related to OI implementation, are mainly found in domain-specific models, e.g., developing a process for organizing OI contests [49] or OI in the public sector [50].

Resulting from the organizational view, the temporary inter-organizational form - the IOP that initiates OI - needs further research. The definition of OI focuses on innovation as a managed process, yet process models, so far, lack the dimension of inter-organizational interests and timelimitation in IOPs. While, e.g., in Grönlund et al. [32], the focal firm could adapt its new product development process to OI, in an IOP, organizations face different established processes, the "difference-paradox" [15]. In focal firms, capabilities for managing OI are built up over time [6], [24], the time-limitation of projects, though, prevents such a lengthy learning process. Assuming IOPs to be more complex or uncertain, Bagherzadeh et al. [29] argue that a more formal collaboration process is necessary for such projects. Therefore, the research question results: How should a process be designed to implement OI initiatives by an inter-organizational project?

\section{Research Methodology}

The research aims at creating an OI process for IOPs to cope with problems experienced in IOP practice, following the Design Science Research (DSR) paradigm and its method framework by Johannesson and Perjons [51] displayed in Figure 1. The present research is development- and evaluation-focused [51] and has a design- and development-centered entry point to the DSR process [52].

A different research strategy and method might be chosen in each step of the design science method framework [51]. While problem explication and definition of requirements are covered by summarizing and analyzing preceding research; in this article, with the study having a designand development-centered entry point, the development and demonstration of the process model (the artifact) applies an action research strategy with a case IOP followed by a survey to validate results within and beyond the case IOP.

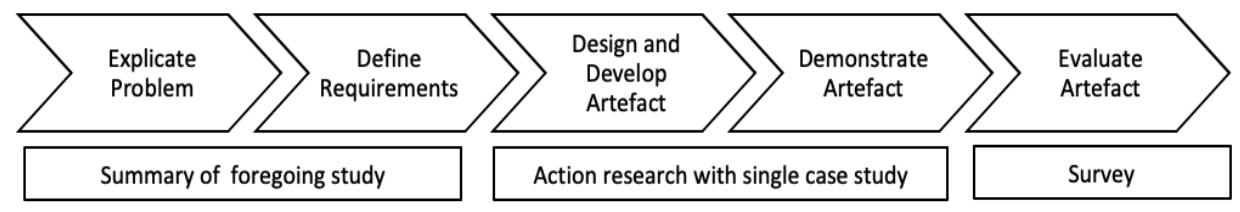

Figure 1. Design Science Research Method Framework of Johannesson and Perjons [51] amended by applied research methods 
The mixed-method approach combines qualitative and quantitative data collection techniques in sequential order [53]. Action research with a case IOP will help develop a problem solution in a specific setting, while the survey will help increase validity beyond the single case. Mixedmethod research is chosen for two reasons [54]. First, both qualitative and quantitative methods have their strengths and weaknesses, which can be balanced by applying both. Action research involves practitioners drawing on scientific and organizational knowledge to solve practitioners' problems and contribute to scientific understanding [55]. However, the external validity of the single case is low [53] and will therefore be increased by a survey to evaluate the artifact. Second, enriching the qualitative findings with quantitative data will help adapt the model for more use cases. For case study research on technology and innovation, Elsahn et al. [56] urge the broadening of research approaches beyond semi-structured interviews. They found that action research was less common in case studies, yet it seems most appropriate for the research question at hand, building towards a process model. A single-case methodology is chosen on the rationale of a revelatory case [57] in which the researcher had the unique opportunity to develop and implement the OI process in an IOP.

The case for the action research is an inter-organizational, international project. The project united nine partners, public museums, research and education institutions, and non-governmental organizations located in five countries. The overall goal of the project was to set up an online platform for developing gamified web apps for museums and attractions. The IOP was partly funded by the European Union (EU). The IOP consortium had planned four hackathon events to feed ideas into the project. Hackathons strive to find solutions by involving the public in a competition event, classifying them as a form of inbound open innovation [23]. Appearing as a software development method in the late 1990s [58], today, hackathons are frequently used outside the software industry, e.g., for urban development [58], healthcare [59], [60] or public services [50]. They are regarded as a "jump start for innovation" [61, p. 12], but also relevant for networking and learning [59]. None of the participating museums or hosting institutions had organized a hackathon before. At the start of this research, issues had been analyzed for the first three hackathons of the IOP. The fourth hackathon in this research would allow the OI process to be developed and tested. Two educational institutions hosted this hackathon within the consortium of the IOP. Seven different museums (non-IOP partners) joined, while seven teams of students and pupils of vocational training, from Germany and Poland, participated in the event. Additionally, specialists from a Finnish university coached the participant teams. The hackathon lasted 30 hours during a weekend in 2019.

The demonstration of the results follows the design science research framework [51], as displayed in Figure 1.

\section{Results}

\subsection{Explicate Problems and Define Requirements}

The diagnosis of the problems encountered in implementing the open innovation initiative in the IOP was the subject of preceding research [62]. In that research, semi-structured interviews were used to collect feedback from practitioners after successively implementing hackathons in three different countries. The IOP partners implementing the hackathons were satisfied with the event organization but not with the achieved results [62]. The reasons identified for the applicability problems encountered, were related to the process of implementation (i.e., no process view of OI, focusing on implementation of OI event, lack of considering definition and exploitation) and to the increased need for communication in IOPs (i.e., differing expectations of IOP partners, little discussion of OI benefits) [62].

The lacking of process view could be explained by the organizational form of the project, which, by definition, is time-limited and focused on the realization of a specific goal [16]. The goal of the case IOP was defined and amended by a detailed task list during the funding 
application, including the hackathon events. Marx and Klotz [62] find that in traditional innovation settings, the focus is on managing and finishing the ongoing project, while in OI, the focus is on a constant search for competencies for future cooperation. The OI initiative in the case IOP is handled as a traditional innovation project, focusing on finishing the current project yet lacking the perspective of OI on future collaboration.

Differing expectations could be related to the concept of equivocality [14] that requires strong communication in IOPs. Further, OI "is not a universal best-practice" [63, p. 606]. The application needs to be justified. Gassmann and Enkel [22, p. 15] argue that "there are significant benefits achieved by a serious discussion on when the open innovation approach should be implemented and when not". Barbosa et al. [17] conclude that an OI project needs a tailored methodology, primarily focusing on clarifying expectations and an open approach to communication.

Therefore, the current study aims at tailoring a process for OI in IOPs, ensuring that differing expectations of IOP partners are negotiated for a proper definition of the OI initiative of the IOP and that time-limitation is considered for exploitation. Applying such a process is expected to lead to satisfaction with the results of the OI activity in the IOP.

\subsection{Design and Develop Artifact}

An action research approach is taken for this phase in the research process. Action research follows a research cycle, starting with diagnosing or constructing the problem, planning the action, taking the intervention, evaluating and reflecting or specifying the learning [51], [64]. Context and purpose [53], [55] as prerequisites towards the action research spiral and diagnosis were summarized in the preceding section.

The initial process model starts with a model for open innovation in the public sector by Mergel [50] displayed in Figure 2. As a dedicated process model for OI, it seems appropriate, as it focuses on public institutions and inbound OI with idea generation, thus representing the partner organizations and the OI initiative in the case IOP. Additionally, this process model has a pre-phase, as a definition stage, and a focus on implementation for exploiting the results from the OI initiative.
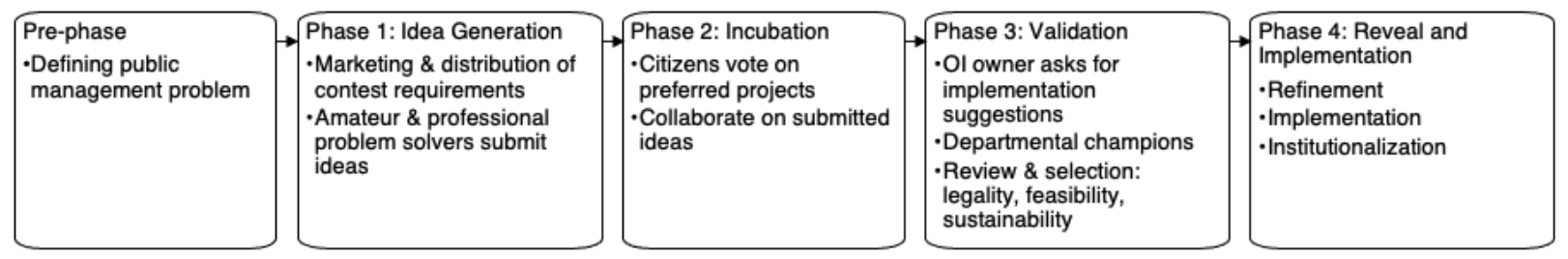

Figure 2. Open innovation phases in the public sector by Mergel [50, Figure I., p. 608], graphically modified

The model is adjusted to address the identified requirements: negotiating expectations to ensure a proper definition and establishing an exploitation phase to frame the operational OI implementation. The initial process model of this research comprises six steps: Clarify goals, Agree outputs, Agree method, Implement ideation, Validate results, Implement and leverage (Figure 3).

With the first three steps, the focus is on defining the OI initiative's purpose and design. Clarify Goals (1) was added to ensure strategic anchoring, as aligning with strategy supports OI actions [38]. This clarification goes beyond the definition of the problem [50] since, in the IOP, all of the institutions involved need a shared understanding of the reason for implementing OI and how this relates to their individual organizations' and their common project goals. Expected outcomes of innovation in networks can differ; often it is the targeted innovation as such, but 
sometimes new knowledge or building relations [9]. Therefore, Agree Outputs (2) was added to negotiate expected results and quality.

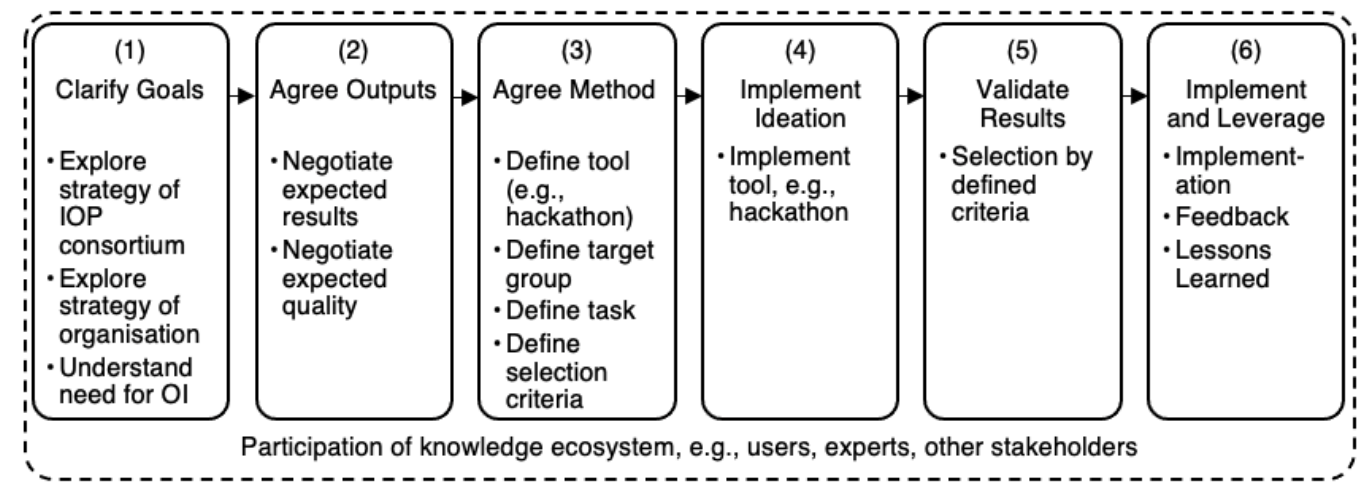

Figure 3. Initial Open Innovation process for inter-organizational projects

Building collective meaning in cross-functional dispersed project teams is vital in communication [65]. Therefore, activity terms such as explore, understand, and negotiate are used for stages 1 and 2. Agree method (3) is added as a definition stage, detailing the OI activity. Based on goals and expected outputs, the OI tool, the participants, the task, and the selection criteria for results are defined. The following three steps, (4)-(6) Implement ideation, Validate results, Implement and leverage, incorporate steps from the initial OI process model [50]. The ideation tool is implemented (4), e.g., the hackathon (in Mergel's model "Idea Generation and Incubation"). Validation of results (5) links to the pre-defined selection criteria (in Mergel's model "Validation"). The results are then implemented and leveraged (6) (in Mergel's model "Reveal and Implementation"), in the case of IOPs also across the consortium. Leveraging is a critical managerial activity in innovation management [7], in the suggested model it includes collecting feedback, lessons learned and implementing the results. Implementing OI initiatives within a business ecosystem can both develop the ecosystem entirely and the participating firms individually [11]. However, a differing understanding of innovation by the ecosystem members is a challenge [11]. For innovation, Moore [66, p. 76] first introduced the business ecosystem concept in which companies "work cooperatively and competitively to support new products, satisfy customer needs, and eventually incorporate the next round of innovations". Radziwon and Bogers [11] characterize business ecosystems by the co-evolution and interdependencies of members, the factual or virtual proximity, and the option for orchestration. Though these concepts exist, reality in public initiatives proves different, with a majority focusing on onedirectional idea gathering [50]. In an IOP, the various partner organizations are embedded in their business ecosystems, potentially at various locations that are accessible for the benefit of knowledge exchange for the IOP. This combination of ecosystems of IOP partner organizations to access knowledge is called the knowledge ecosystem in this article. The exchange, with the knowledge ecosystem of the IOP, is added to the initial process model, where linear knowledge transfer is replaced by a continuous inflow and outflow of knowledge with a more extensive range of stakeholders [67].

\subsection{Demonstrate Artifact}

The process was applied and demonstrated by implementing an additional hackathon in the case IOP. Applying the suggested process resulted in a different design of the OI initiative, though, in the similar IOP (Table 2).

Firstly, the clarification of goals revealed differences in the goals for the IOP consortium and the individual organizations implementing the OI initiative. While the IOP's goal was to gain ideas for the digital platform, the organizers' additional goals were networking and learning opportunities for pupils and students. Realizing this difference affected both the expected outputs 
(still containing ideas or code, but eliminating ready solutions for the favor of (paper-) prototypes and conceptions), but also the communication of the $\mathrm{OI}$ initiative (changing from a focus on competition and results to a focus on learning), the team set up, and the integration of the IOP's knowledge ecosystem (Table 2). As the word hackathon is firmly attributed to coding [59], communication was re-designed inviting participants to a "Creative workshop for IT in our museums". Aiming at learning and networking, the involvement of the IOP's knowledge ecosystem changed, with museum representatives becoming part of the teams instead of having a mentor role as in the preceding hackathons.

Secondly, following the process, the leveraging phase was established more broadly. Lessons learned were documented in a guide for hackathons in museums and then published. The goal of building a regional network was implemented. The idea implementation was followed up individually by the participating museums, outside the IOP. Results were shared with the IOP consortium, although these proved beyond the IOP's scope and resources.

Table 2. Characteristics of OI in the case IOP (extended from [62])

\begin{tabular}{|c|c|c|}
\hline & \begin{tabular}{|l|}
3 Cases \\
{$[62]$}
\end{tabular} & $\begin{array}{l}1 \text { Case } \\
\text { with OI Process in IOP }\end{array}$ \\
\hline OI mode & Hackathon 30 hours & Ideation event 30 hours \\
\hline Focus of event & Competition, Results & Learning \\
\hline Participant types & Students, professional developers & Students, pupils \\
\hline Team rules & None & $\begin{array}{l}5+1=6 \text { (i.e., } 5 \text { students/pupils }+1 \text { museum } \\
\text { representative) }\end{array}$ \\
\hline $\begin{array}{l}\text { Involvement of } \\
\text { museums }\end{array}$ & $\begin{array}{l}\text { Coaching: } 1-2 \text { museums as mentors and } \\
\text { organizers }\end{array}$ & Participating: 7 museums as team members \\
\hline Briefing of participants & $\begin{array}{l}\text { Narrow challenge: Highlighted } \\
\text { problems in a single museum, partly } \\
\text { proposed solutions }\end{array}$ & $\begin{array}{l}\text { Broad challenge: Game for a smartphone to } \\
\text { motivate museum visit, proposed } \\
\text { stories/topics from various museums }\end{array}$ \\
\hline Accepted results & Ideas, code, ready solutions & Ideas, (paper-) prototypes, code, conceptions \\
\hline
\end{tabular}

A focus group was conducted five weeks after the IOPs hackathon, with four representatives from museums, five organizers, and one representative from a museum association. Notes were taken during that discussion and coded. The organizers confirmed their satisfaction with the results of the OI activity in that discussion. The qualitative data from the focus group helped identify elements for adjusting the model: regarding wording, the adaptation of individual items, and distinguishing the results transfer occurring both within and outside of the IOP. The adjusted model is shown in Figure 4.

For enhanced clarity of the process model, a consistent naming approach was chosen by combining activity and noun, speaking of the OI method, instead of specifically hackathon, and rephrasing individual items. Adding or amending selected items was done regarding:

- Roles: The focus group proved that integrating a museum representative into the team needs a more detailed role clarification. One host said, "the group felt pushed. They want as much freedom as possible", while a museum representative realized "I have to step back more", and another asked, "Which role do I have exactly?". Thus, role clarification needed to be added to the process model (3).

- Communication: The engagement with the IOP's knowledge ecosystem prevailed in phases (3) and (4). Therefore, in (3), the definition of the communication with the IOP's knowledge ecosystem needed to be added and marked more clearly in the model.

- Resources: Resources for implementing the OI activity were clearly outlined in the IOP, yet resources for implementing (unpredictable) results from the OI initiative had not been defined beforehand. Therefore, the results from the OI initiative could not be directly integrated into the case IOP. Thus, in the model in phase (2), negotiating resources for OI 
activity and for implementing results of OI were split into two different activities, and the phase was renamed to Agree Input and Output of OI.

- Selection: While during the hackathon, a jury selected a winning idea, the discussion showed that a second step is needed for the evaluation of the implementation by either the IOP, an individual organization or a network. While implementing the OI method, selecting ideas in a competition-based activity should be covered. However, the validation of results (5) needed clarification to document all results achieved and select results for implementation, separately.

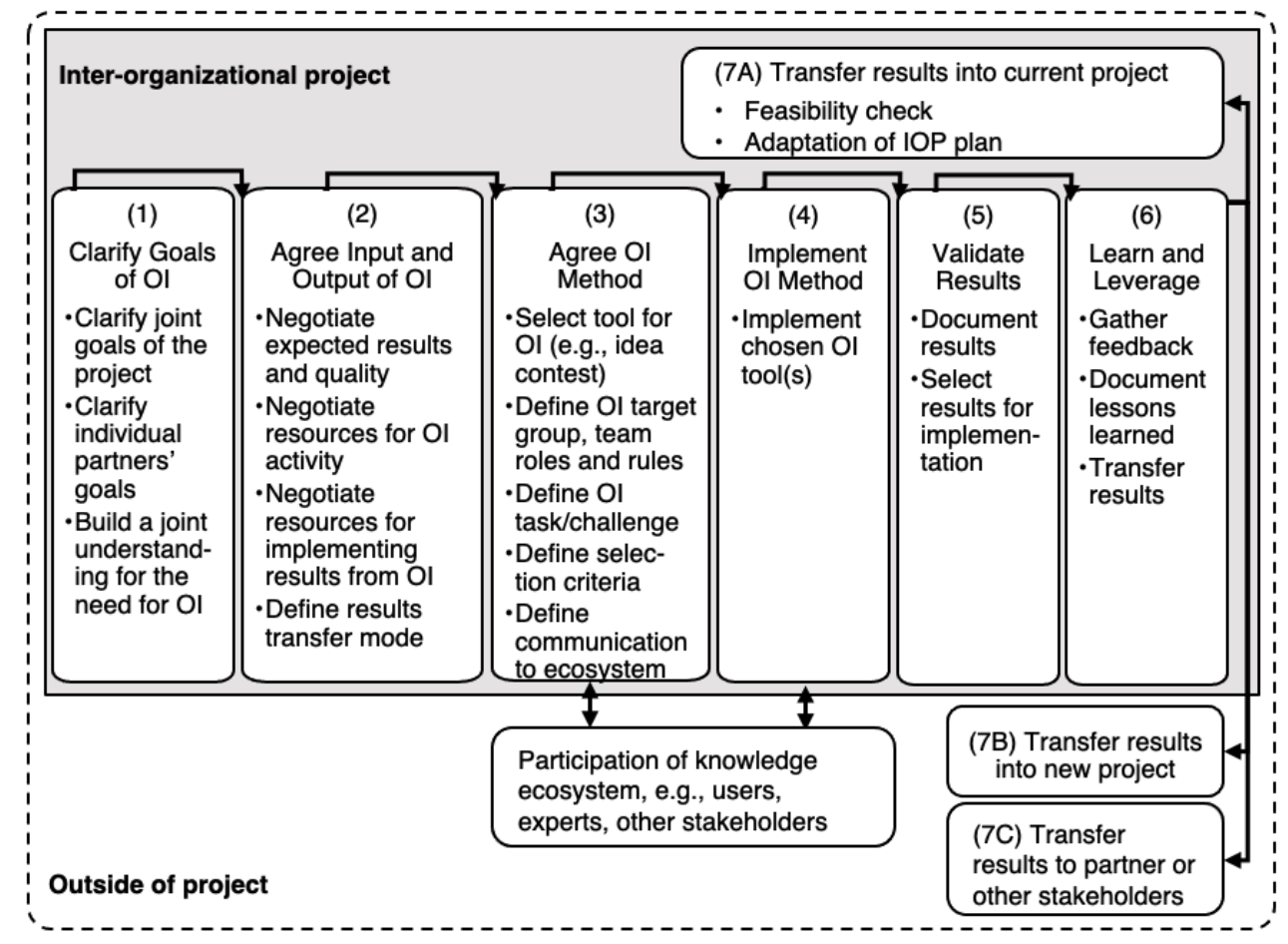

Figure 4. Adjusted Open Innovation process for inter-organizational projects

A significant change resulted from feedback from both organizers and museums regarding the results transfer. From the organizers' viewpoint, the expected knowledge transfer in terms of intellectual property needs to be defined and outlined in the terms and conditions for the OI initiative. In other studies, property rights were identified as a significant barrier towards involving external sources in ideation [68]. Gama [69] argues that different formal and informal appropriation methods are combined for collaborative ideation. Therefore, the activity 'define results transfer mode' needed to be added in phase (2).

The most considerable change to the model was towards the end of the OI process. While one museum considered "integrating the ideas in other already planned projects", others confirmed it "has kicked off further ideas in the museum". The resources, both knowledge and financial, and day-to-day tasks hindered direct implementation ("there are so many daily tasks"). Thus, it seemed ideas were triggered; however, there was a need to plan upfront how to incorporate the results by participating organizations both inside and outside the IOP, thus considering both inbound and outbound options. The after-event phase presents most challenges [58], [60]. Therefore, phase (7) was rephrased to transferring results either within the IOP or to other projects or stakeholders (see (7A)-(7C) Figure 4). Additionally, the activities within IOP governance were marked more clearly to distinguish them from the border-spanning activities.

With the participation of the IOP's knowledge ecosystem and the various modes of transferring results from the OI initiative within the IOP to the outside, the new process moved from an outside-in perspective to a combination of outbound and inbound innovation. As this 
adjusted model could not be implemented in the case IOP, due to the limitation of time and resources, a different approach - a small scale survey - was taken to evaluate the model.

\subsection{Evaluate Artifact}

With the survey, two aspects are evaluated: firstly, if there is a difference of perception of the proposed model between case IOP participants and non-participants; and secondly, the perceived importance of the model's activity items and its overall suitability. For step one, the hypothesis is that there is a significant difference between evaluating the proposed items of the model by the case IOP participants (group 1) and by representatives of other IOPs (group 2), as group 1 is familiar with the specific case that the model was built for. In the survey part 1, the perceived importance of each activity item was evaluated, measured on a 5-point scale (1 not at all important, slightly important, important, fairly important, 5 very important). The second part showed the model to the respondents as a graphic (Figure 4). The respondents were then asked how well, overall, the model is suitable for implementing an OI activity in an Interreg IOP on a 5 -point scale (1 does not suit at all to 5 suits perfectly).

Table 3. Test results for activities and total model for differences in group 1 and 2 , ${ }^{*} p=<0.05$

\begin{tabular}{|c|c|c|c|c|c|c|}
\hline $\begin{array}{l}\text { Item } \\
\text { nr. }\end{array}$ & Activity item & \begin{tabular}{|l|} 
Mann- \\
Whitney- \\
U
\end{tabular} & $\begin{array}{l}\text { Exact Sig. } \\
{[2 *(1-\text { tailed }} \\
\text { Sig.)] }\end{array}$ & \begin{tabular}{|l|}
$\begin{array}{l}\text { Pearson } \\
(r)\end{array}$ \\
\end{tabular} & Mean & Mode \\
\hline 1 & Clarify joint goals of the project for OI activity & 17.500 & 0.937 & 0.036 & 4.750 & 5 \\
\hline 2 & Clarify individual partners' goals regarding OI activity & 18.000 & 1.000 & 0.000 & 4.333 & 5 \\
\hline 3 & $\begin{array}{l}\text { Building joint understanding for the need for OI } \\
\text { activity }\end{array}$ & 5.000 & 0.041 & $0.656^{*}$ & 4.333 & 5 \\
\hline 4 & Negotiate expected OI results and quality & 12.000 & 0.394 & 0.301 & 3.750 & 3 \\
\hline 5 & Negotiate resources for OI activity & 13.000 & 0.485 & 0.246 & 3.833 & 3 \\
\hline 6 & $\begin{array}{l}\text { Negotiate resources for implementing results from OI } \\
\text { activity }\end{array}$ & 11.500 & 0.310 & 0.320 & 4.083 & 4 \\
\hline 7 & $\begin{array}{l}\text { Define transfer mode of OI results (e.g., intellectual } \\
\text { property rights) }\end{array}$ & 12.000 & 0.394 & 0.300 & 4.250 & 5 \\
\hline 8 & Select tool for OI (e.g., idea contest) & 14.000 & 0.589 & 0.197 & 4.167 & 5 \\
\hline 9 & Define OI target group, team roles and rules & 10.000 & 0.240 & 0.404 & 4.333 & 5 \\
\hline 10 & Define OI task/challenge & 17.000 & 0.937 & 0.051 & 4.167 & 4 \\
\hline 11 & Define selection criteria for OI results & 12.500 & 0.394 & 0.271 & 3.917 & 3 \\
\hline 12 & Define communication to stakeholders/ecosystem & 12.000 & 0.394 & 0.296 & 3.917 & 3 \\
\hline 13 & Involve knowledge ecosystem & 9.000 & 0.180 & 0.449 & 3.833 & 5 \\
\hline 14 & Implement chosen OI activity & 17.000 & 0.937 & 0.049 & 4.000 & 5 \\
\hline 15 & Document results from OI activity & 18.000 & 1.000 & 0.000 & 3.667 & 3 \\
\hline 16 & Select results from OI activity for implementation & 16.000 & 0.818 & 0.097 & 4.000 & 5 \\
\hline 17 & Gather feedback on OI activity & 13.000 & 0.485 & 0.245 & 3.750 & 3 \\
\hline 18 & Document lessons learned on OI activity & 10.500 & 0.240 & 0.367 & 3.917 & 5 \\
\hline 19 & $\begin{array}{l}\text { Transfer OI results for implementation in current } \\
\text { project }\end{array}$ & 13.000 & 0.485 & 0.249 & 4.167 & 5 \\
\hline 20 & Transfer OI results for implementation in new project & 16.500 & 0.818 & 0.072 & 3.417 & 4 \\
\hline 21 & $\begin{array}{l}\text { Transfer OI results for implementation by any project } \\
\text { partner }\end{array}$ & 9.500 & 0.180 & 0.424 & 3.500 & 3 \\
\hline 22 & $\begin{array}{l}\text { Transfer OI results for implementation by any } \\
\text { stakeholder }\end{array}$ & 5.000 & 0.041 & $0.618^{*}$ & 3.250 & 3 \\
\hline 23 & $\begin{array}{l}\text { In your view, how well does this process model suit for } \\
\text { implementing an Open Innovation activity in an } \\
\text { Interreg project? }\end{array}$ & 11.000 & 0.310 & 0.360 & 4.417 & 5 \\
\hline
\end{tabular}


Regarding the scales as ordinal, the Mann-Whitney U Test is chosen as a test statistic for bivariate data of independent samples, with an equal size of $n$ for both groups improving the validity of the test [70]. The Mann-Whitney $U$ Test is suited for smaller sample size $\left(n_{1}+n_{2}<30\right)$ [71] (here: representatives of the case IOP (group 1, $\left.n_{1}=6\right)$ and representatives of other IOPs (group 2, $n_{2}=6$ )). For such cases, the test statistic $U$ and the exact significance should be used [71]. The significance criterion is set at $\alpha<0.05$ [53], [72]. In case of significance, the effect size is evaluated by Pearson $(r)$, since $n_{1}=n_{2}$ [71], with $r=0.10$ a small, 0.30 a medium and 0.50 a strong effect [72].

Only two items show a difference between groups 1 and 2 at a significant level of $p<0.05$ : items 3 and 22 (Table 3). The effect size $r$ is 0.656 and 0.618 respectively, thus a strong effect [72]. For these two items, the hypothesis is accepted but rejected for all other items. Thus, the model developed seems to be judged similarly outside of the case IOP. For items 3 and 22, the differences are caused by perceived lower importance in group 1. While item 3 is still somewhat crucial for group 1, it seemed acceptable to stay within the model. Item 22 surprisingly falls below the score of 'important' in group 1 (Table 4). The difference between the two groups cannot be explained with the available data. However, as in group 2, this item is considered important (mean/mode $=4)$; hence it is kept in the model. Each of the other individual items 1 to 21 , that build the suggested process, is considered important to very important (mean, mode). Thus, the items selected for the model are of relevance.

Table 4. Analysis of items with a significant difference in groups 1 and 2

\begin{tabular}{|l|l|l|l|l|l|l|l|}
\hline $\begin{array}{l}\text { Item } \\
\text { nr. }\end{array}$ & Activity item & \multicolumn{2}{|l|}{ All $(\boldsymbol{n = 1 2})$} & \multicolumn{2}{l|}{$\begin{array}{l}\text { Group 1 case IOP } \\
(\boldsymbol{n = 6})\end{array}$} & \multicolumn{2}{l}{$\begin{array}{l}\text { Group 2 non-case IOP } \\
(\boldsymbol{n}=\mathbf{6})\end{array}$} \\
\cline { 3 - 8 } & & Mean & Mode & Mean & Mode & Mean & Mode \\
\hline 3 & $\begin{array}{l}\text { Building joint understanding for the } \\
\text { need for OI activity }\end{array}$ & 4.333 & 5 & 3.833 & 4 & 4.833 & 5 \\
\hline 22 & $\begin{array}{l}\text { Transfer OI results for } \\
\text { implementation by any stakeholder }\end{array}$ & 3.250 & 3 & 2.500 & 3 & 4.000 & 4 \\
\hline
\end{tabular}

Item 23 of the survey considers the overall suitability of the process model for implementing $\mathrm{OI}$ in an Interreg IOP. With no significant difference between the two groups in their view of the model (Table 3), we have to reject the hypothesis and accept the null hypothesis. This item has a mode of 5 (suits perfectly) and a mean of 4.417; thus, a strong tendency towards being a suitable process for Open Innovation within an Interreg IOP, a specific type of IOP researched in this study. The same notion is also reflected by free text answers such as "looks very good to me", "well organized and detailed", "adequate and comprehensive", and "the process fits very well with our findings on how to implement OI in an Interreg project". However, despite overall fit, two suggestions are made for further flexibility and iteration: "cannot accommodate any change of plans at a later stage and cannot be combined with an agile approach" or even more concrete "a feedback loop between 5 (Validate results) and 3 (Agree OI method) could be added. Being aware of the potential flaws in the set-up will enable the project partners to steer the methods in the right direction".

\section{Discussion}

The research project investigated how an IOP could design a process to implement OI initiatives. The adjusted process model (Figure 4) was positively rated for the overall model and the individual activity items by the case IOP and other IOP representatives. Applying a dedicated process for managing OI was found beneficial in extant studies [24], [47], [48], with several authors urging for a tailored innovation process [41], [45]. The positive perception of the proposed model could also be explained by the "difference paradox" [15, p. 11]: with the different organizations having their different innovation practices, there is a need for the IOP to 
shape and negotiate its tailored practice, as is emphasized in the model. The positive perception of the suggested process could be explained by the stretching practice concept suggested by Sydow and Müller-Seitz [28]: to apply a practice from a known area to an area of uncertainty. In the case IOP, the introduction of OI practices was perceived as new. However, the proposed process model is a reminder of a project life cycle from project management (e.g., [16]: organizing and preparing, carrying out the work and closing the project), a subject familiar to the IOP members. The proposed OI process could be viewed as a small project within the IOP. Since the IOP partners are familiar with project practices, the proposed process might have appeared familiar as a stretching practice from project implementation to the specific OI initiative and therefore gained positive evaluation.

The rating of individual activities in the model reveals that those relating to phase (1), i.e., clarifying goals, have the highest scores of all activities (Mean 4.333-4.750), while those related to the transfer of OI results (7) have the lowest scores (Mean 3.250-3.500) except for the transfer of results incorporated within the present IOP (Mean 4.167) (7A). The high importance of clarifying activities amongst the IOP partners can be attributed to the concept of equivocality that might reduce project performance in innovation in IOPs [14]. To combat equivocality, building collective meaning in dispersed teams [65] might raise the perception of the importance of this clarification stage.

The project view could explain the medium importance of transfer activities outside of the IOP, focusing on the time-limited implementation of a unique result [16]. That might prevent projects from considering outbound options of innovation activities as also found less prevalent in firms [73]. The Interreg IOPs follow a specific lifecycle [74] based on detailed planning to be contracted by funding authorities. Since underlying contracts impact the transfer of knowledge in inter-organizational projects [75], it can be assumed that the contract with the funding provider influences how the project is implemented: focusing only on the contracted results.

The flexibility for iterations in the model, that two study respondents point out, suggests an adaptation for feedback cycles. For Cooper's Stage-Gate process, Cooper [41] argues that iterations and adaptations are possible despite the graphical representation seeming linear. The present model should be understood in the same way, as a starting point open for tailoring to specific IOP circumstances or being repeated for various OI activities. The suggestion of an agile management approach can be related to the phase after the OI results are transferred to a specific mode of governance for exploitation, for the backend of innovation, as suggested as one mode of implementation by Gausemeier et al. [21], depending on the type of project.

\subsection{Theoretical Contribution}

The research suggests, tests, and evaluates a process model for implementing OI initiatives in IOPs, with the sample of Interreg IOPs. It covers an organizational dimension of OI that has largely been neglected: temporary, inter-organizational structures that initiate OI activities. Few studies so far have acknowledged the need for further understanding of innovation, even across boundaries of inter-organizational structures [20], [28].

The suggested process model extends existing models [46], [50] with an IOP perspective. The IOP is specific because it meets challenges of inter-organizational organizing, e.g., "difference paradox" [15] or equivocality [14], as well as of the characteristics of a project such as a temporariness, uniqueness of task, and goal orientation [16]. Apart from the operational stage, the model emphasizes the preparation and termination stages that Bican et al. [46] recommend. Further, the process model demonstrates the need for mutual exchange with the knowledge ecosystem of the IOP, thus encouraging inbound and outbound knowledge flows as well as the transferring results to non-temporary forms of governance.

The research further shows that while all activity items are considered of medium to high importance, those attributed to clarifying goals are considered to be of the highest importance. In contrast, those attributed to transferring results outside the IOP boundaries are considered of the 
lowest importance. It thus seems that IOPs might be "net "takers"” of knowledge as Chesbrough and Brunswicker [73, p.17] also found for large firms.

\subsection{Managerial Contribution}

Practitioners managing IOPs are supported by a tried and tested OI process for IOPs. There are many modes of OI to choose from [73]. However, in an IOP, the stage before implementing the OI initiative is crucial, due to diverse partners' expectations regarding the goals of the total IOP consortium and the individual IOP partner organizations.

Of all activity items presented, those regarding the transfer of results, especially outside the IOP, were regarded as least important. While that supports the project view on focusing on getting a particular result produced by several partners in a limited time, especially in the field of EU-funding, this focus might impede the intended dissemination of publicly funded results beyond IOP consortia. The findings can encourage IOP funding providers to enable the IOP members to see benefits from externalizing knowledge beyond the IOP, in order to enhance the perceived importance of outbound activities in such projects.

\subsection{Limitations}

The environment of the selected case limits this study. The case in the action research cycle and the survey addressed IOPs that received funding from an EU program, mainly involving not-forprofit organizations. Referring to Chesbrough and Bogers' [4, p. 12] definition of OI, the proposed process suggests how to organize knowledge flows "in line with the organization's business model". It could be argued that this model is specific to the business model of EU funded IOPs only. Therefore, future research should apply the process in other IOP environments. However, a contribution is made for not-for-profit environments [3].

As limited to a single case and a small sample survey, the study's results cannot be generalized. The researcher was involved in the action research approach with deep exchange with practitioners, which might bias the results. However, this allowed the tailoring of the approach and immediate interaction needed for action research. A mixed-method approach was taken to combat the single case limitations. While statistical calculation with the Whitney-Mann$\mathrm{U}$ test proved that both groups largely agree in their judgements of the fit of the overall model and single activity items, it could be argued that the test power was too small to detect differences in their perception. Therefore, a future recommendation is to enlarge the sample.

\section{Conclusion}

This article describes a Design Science Research study to develop an OI process for IOPs. It takes up the call for further research on OI in inter-organizational structures, focusing on the organizational form of inter-organizational projects adding the aspect of temporariness. Though limited by a single case IOP and a small sample survey, the suggested process for OI initiatives in IOPs proved equally relevant to the case IOP representatives and those involved in other IOPs. The suggested process model can support OI practice in IOPs, as a practice to overcome the "difference paradox" when IOPs initiate OI activities.

The potential for future research for the perspective of OI initiated by temporary, interorganizational structures is manifold. Firstly, the process model should be tested in additional case studies. Both broadening to other IOP settings, e.g., for-profit partnerships and other OI modes, would enhance the model's validity and provide room to investigate iterative phase concepts. A higher number of samples could improve the statistical power. Secondly, the longterm effects of OI initiatives of temporary IOPs need further research. Melo et al. [6] suggest that a vanguard project is vital on the path towards full incorporation of OI in an organization. Could Interreg projects and IOPs act as vanguard projects in OI for organizations? Thirdly, the transfer 
mode of OI results from IOPs provides room for future research. While transfer modes were considered less important, an investigation of potential benefits and prevailing transfer modes considering the temporariness of the IOP seems beneficial both for theory and practice.

\section{Acknowledgement}

The project team of the project "BalticMuseums: LoveIT!", partly-financed by the Interreg South Baltic program in the European Regional Development Fund, has given me the unique opportunity to conduct my research. To all members of the project and the survey respondents, I would like to express my deep gratitude.

\section{References}

[1] H. T. T. Le, Q. T. M. Dao, V. C. Pham, and D. T. Tran, "Global trend of open innovation research: A bibliometric analysis," Cogent Bus. Manag., vol. 6, no. 1633808, pp. 1-20, 2019. Available: https://doi.org/10.1080/23311975.2019.1633808

[2] W. Vanhaverbeke, "The Interorganizational Context of Open Innovation," Open Innovation: Researching a New Paradigm, H. Chesbrough, W. Vanhaverbeke, and J. West, Eds. Oxford: Oxford University Press, pp. 205-219, 2006.

[3] J. West and M. Bogers, “Open innovation: current status and research opportunities," Innov. Manag. Policy Pract., vol. 19, no. 1, pp. 43-50, 2017. Available: https://doi.org/10.1080/14479338.2016.1258995

[4] H. Chesbrough and M. Bogers, "Explicating Open Innovation: Clarifying an Emerging Paradigm for Understanding Innovation," New Frontiers in Open Innovation, H. Chesbrough, W. Vanhaverbeke, and J. West, Eds. Oxford: Oxford University Press, pp. 3-28, 2014. Available: https://doi.org/10.1093/acprof:oso/9780199682461.003.0001

[5] M. R. Guertler and N. Sick, "Exploring the enabling effects of project management for SMEs in adopting open innovation - A framework for partner search and selection in open innovation projects," Int. J. Proj. Manag., vol. 39, no. 2, pp. 102-144, 2021. Available: https://doi.org/10.1016/j.ijproman.2020.06.007

[6] J. C. F. de Melo, M. S. Salerno, J. S. Freitas, R. B. Bagno, and V. C. Brasil, "From open innovation projects to open innovation project management capabilities: A process-based approach," Int. J. Proj. Manag., vol. 38, no. 5, pp. 278-290, 2020. Available: https://doi.org/10.1016/j.ijproman.2020.06.006

[7] L. Aarikka-Stenroos, E. Jaakkola, D. Harrison, and T. Mäkitalo-Keinonen, "How to manage innovation processes in extensive networks: A longitudinal study," Ind. Mark. Manag., vol. 67, no. April 2016, pp. 88105, 2017. Available: https://doi.org/10.1016/j.indmarman.2017.09.014

[8] G. J. Fisher and W. J. Qualls, “A framework of interfirm open innovation: relationship and knowledge based perspectives," J. Bus. Ind. Mark., vol. 33, no. 2, pp. 240-250, 2018. Available: https://doi.org/10.1108/JBIM11-2016-0276

[9] C. Reypens, A. Lievens, and V. Blazevic, "Leveraging value in multi-stakeholder innovation networks: A process framework for value co-creation and capture," Ind. Mark. Manag., vol. 2016, no. 56, pp. 40-50, 2016. Available: https://doi.org/10.1016/j.indmarman.2016.03.005

[10] V. Nestle, Open Innovation im Cluster. Wiesbaden: Gabler Verlag Springer Fachmedien, 2011 (in German).

[11] A. Radziwon and M. Bogers, "Open innovation in SMEs: Exploring inter-organizational relationships in an ecosystem," Technol. Forecast. Soc. Change, vol. 146, pp. 573-587, 2018. Available: https://doi.org/10.1016/j.techfore.2018.04.021

[12] S. von Danwitz, "Managing inter-firm projects: A systematic review and directions for future research," Int. J. Proj. Manag., vol. 36, no. 3, pp. 525-541, 2018. Available: https://doi.org/10.1016/j.ijproman.2017.11.004

[13] J. Sydow and T. Braun, "Projects as temporary organizations: An agenda for further theorizing the interorganizational dimension," Int. J. Proj. Manag., vol. 36, no. 1, pp. 4-11, 2018. Available: https://doi.org/10.1016/j.ijproman.2017.04.012

[14] P. E. Eriksson, P. C. Patel, D. R. Sjödin, J. Frishammar, and V. Parida, "Managing Interorganizational Innovation Projects: Mitigating the Negative Effects of Equivocality Through Knowledge Search Strategies," Long Range Plann., vol. 49, no. 6, pp. 691-705, 2016. Available: https://doi.org/10.1016/j.lrp.2016.05.006

[15] R. DeFillippi and J. Sydow, "Project Networks: Governance Choices and Paradoxical Tensions," Proj. Manag. 
J., vol. 47, no. 5, pp. 6-17, 2016. Available: https://doi.org/10.1177/875697281604700502

[16] Project Management Institute, A Guide to the Project Management Body of Knowledge (PMBOK® Guide), 5th ed. Newtown Square: Project Management Institute, 2013. Available: https://doi.org/10.1002/pmj.21345

[17] A. P. F. P. L. Barbosa, M. S. Salerno, P. T. de S. Nascimento, A. Albala, F. P. Maranzato, and D. Tamoschus, "Configurations of project management practices to enhance the performance of open innovation R\&D projects," Int. J. Proj. Manag., vol. 39, no. 2, pp. 128-138, 2021. Available: https://doi.org/10.1016/j.ijproman.2020.06.005

[18] J. Du, B. Leten, and W. Vanhaverbeke, "Managing open innovation projects with science-based and marketbased partners," Res. Policy, vol. 43, no. 5, pp. 828-840, $2014 . \quad$ Available: https://doi.org/10.1016/j.respol.2013.12.008

[19] L. A. de V. Gomes, H. Lopez-Vega, and A. L. F. Facin, "Playing chess or playing poker? Assessment of uncertainty propagation in open innovation projects," Int. J. Proj. Manag., vol. 39, no. 2, pp. 154-169, 2021. Available: https://doi.org/10.1016/j.ijproman.2020.07.002

[20] M. Jaekel, A. Wallin, and M. Isomursu, "Guiding Networked Innovation Projects Towards Commercial Success - a Case Study of an EU Innovation Programme with Implications for Targeted Open Innovation," J. Knowl. Econ., vol. 6, no. 3, pp. 625-639, 2015. Available: https://doi.org/10.1007/s13132-015-0274-3

[21] J. Gausemeier, R. Dumitrescu, J. Echterfeld, T. Pfänder, D. Steffen, and F. Thielemann, Innovationen für die Märkte von morgen. München: Carl Hanser Verlag, 2019 (in German). Available: https://doi.org/10.3139/9783446429727.fm

[22] O. Gassmann and E. Enkel, "Theory of Open Innovation: Three Core Process Archetypes.," in $R \& D$ Management Conference (RADMA) 2004, pp. 1-18, 2004.

[23] F. Piller and J. West, "Firms, Users, and Innovation: An Interactive Model of Coupled Open Innovation," New Frontiers in Open Innovation, H. Chesbrough, W. Vanhaverbeke, and J. West, Eds. Oxford: Oxford University Press, pp. 29-49, 2014. Available: https://doi.org/10.1093/acprof:oso/9780199682461.003.0002

[24] A. Zynga, K. Diener, C. Ihl, D. Lüttgens, F. Piller, and B. Scherb, "Making Open Innovation Stick," Res. Technol. Manag., vol. 61, no. 4, pp. 16-25, 2018. Available: https://doi.org/10.1080/08956308.2018.1471273

[25] R. A. Lundin and A. Söderholm, "A theory of the temporary organization," Scand. J. Manag., vol. 11, no. 4, pp. 437-455, 1995. Available: https://doi.org/10.1016/0956-5221(95)00036-U

[26] R. M. Bakker, R. J. DeFillippi, A. Schwab, and J. Sydow, "Temporary Organizing: Promises, Processes, Problems," Organ. Stud., vol. 37, no. 12, pp. 1703-1719, Dec. 2016. Available: https://doi.org/10.1177/0170840616655982

[27] D. J. Teece, "Inter-organizational requirements of the innovation process," Manag. Decis. Econ., vol. SI, no. 1989, pp. 35-42, 1989.

[28] J. Sydow and G. Müller-Seitz, "Open innovation at the interorganizational network level - Stretching practices to face technological discontinuities in the semiconductor industry," Technol. Forecast. Soc. Change, vol. 155, no. C, p. 119398, 2020. Available: https://doi.org/10.1016/j.techfore.2018.07.036

[29] M. Bagherzadeh, S. Markovic, and M. Bogers, "Managing Open Innovation: A Project-Level Perspective," IEEE Trans. Eng. Manag., vol. 68, no. 1, pp. 301-316, 2021. Available: https://doi.org/10.1109/TEM.2019.2949714

[30] M. Bagherzadeh, A. Gurca, and S. Brunswicker, "Problem Types and Open Innovation Governance Modes: A Project-Level Empirical Exploration,” IEEE Trans. Eng. Manag., pp. 1-15, 2019. Available: https://doi.org/10.1109/TEM.2019.2942132

[31] N. Lakemond, L. Bengtsson, K. Laursen, and F. Tell, "Match and manage: the use of knowledge matching and project management to integrate knowledge in collaborative inbound open innovation," Ind. Corp. Chang., vol. 25, no. 2, pp. 333-352, 2016. Available: https://doi.org/10.1093/icc/dtw004

[32] J. Grönlund, D. Rönnberg Sjödin, and J. Frishammar, "Open Innovation and the Stage-Gate process: A revised model for new product development," Calif. Manage. Rev., vol. 52, no. 3, pp. 106-132, 2010. Available: https://doi.org/10.1525/cmr.2010.52.3.106

[33] A. Spithoven, W. Vanhaverbeke, and N. Roijakkers, "Open innovation practices in SMEs and large enterprises," Small Bus. Econ., vol. 41, no. 3, pp. 537-562, 2013. Available: https://doi.org/10.1007/s11187-012-9453-9

[34] S. Nambisan and M. Sawhney, "Orchestration Processes in Network-Centric Innovation: Evidence From the Field," Acad. Manag. Perspect., vol. 25, no. 3, pp. 40-57, 2011. Available: 
https://doi.org/10.5465/AMP.2011.63886529

[35] J. Tidd and J. Bessant, Managing Innovation, 5th ed. Chichester, UK: John Wiley \& Sons, 2013.

[36] A. Moretti, The network organization: A governance perspective on structure, dynamics and performance. Cham: Palgrave Macmillan, 2017.

[37] C. Jones and B. B. Lichtenstein, "Temporary Inter-organizational Projects: How Temporal and Social Embeddedness Enhance Coordination and Manage Uncertainty," The Oxford Handbook of InterOrganizational Relations, S. Cropper, C. Huxham, M. Ebers, and P. Smith Ring, Eds. Oxford: Oxford University Press, 2008, pp. 231-255. Available: https://doi.org/10.1093/oxfordhb/9780199282944.003.0009

[38] W. Vanhaverbeke and M. Cloodt, "Theories of the Firm and Open Innovation," in New Frontiers in Open Innovation, H. Chesbrough, W. Vanhaverbeke, and J. West, Eds. Oxford: Oxford University Press, 2014, pp. 256-280. Available: https://doi.org/10.1093/acprof:oso/9780199682461.003.0014

[39] W. Burr, Innovationen in Organisationen, 2nd ed. Stuttgart: W. Kohlhammer, 2017 (in German).

[40] H. Schäperkötter, "Orientierung in der komplexen Welt durch Innovationsmanagement," in Innovationsmanagement 4.0, R. Völker and A. Friesenhahn, Eds. Stuttgart: W. Kohlhammer, pp. 40-46, 2018 (in German).

[41] R. G. Cooper, "The Stage-Gate Idea-to-Launch Process - Update, What's New and NexGen Systems," J. Prod. Innov. Manag., vol. 25, no. 3, pp. 213-232, 2008. Available: https://doi.org/10.1111/j.15405885.2008.00296.x

[42] M. T. Hansen and J. Birkinshaw, "The innovation value chain," Harv. Bus. Rev., vol. 85, no. 6, pp. 121-131, 2007.

[43] H. Van Der Meer, "Open innovation - the Dutch treat: Challenges in thinking in business models," Creat. Innov. Manag., vol. 16, no. 2, pp. 192-202, 2007. Available: https://doi.org/10.1111/j.1467-8691.2007.00433.x

[44] J. West and M. Bogers, "Leveraging external sources of innovation: A review of research on open innovation," J. Prod. Innov. Manag., vol. 31, no. 4, pp. 814-831, 2014. Available: https://doi.org/10.1111/jpim.12125

[45] G. Pisano, "You need an innovation strategy," Harv. Bus. Rev., pp. 45-54, June 2015.

[46] P. M. Bican, C. C. Guderian, and A. Ringbeck, "Managing knowledge in open innovation processes: an intellectual property perspective," J. Knowl. Manag., vol. 21, no. 6, pp. 1384-1405, 2017. Available: https://doi.org/10.1108/JKM-11-2016-0509

[47] I. Haase, Kommunikation in Open Innovation-Prozessen von kleinen Unternehmen, 2nd ed. Wiesbaden: Springer Fachmedien Wiesbaden, 2019 (in German). Available: https://doi.org/10.1007/978-3-658-23822-3

[48] D. L. Roberts, F. T. Piller, and D. Lüttgens, "Mapping the Impact of Social Media for Innovation: The Role of Social Media in Explaining Innovation Performance in the PDMA Comparative Performance Assessment Study," J. Prod. Innov. Manag., vol. 33, no. SI, pp. 117-135, 2016. Available: https://doi.org/10.1111/jpim.12341

[49] A. Hjalmarsson, G. Juell-Skielse, and P. Johannesson, Open Digital Innovation Contest. Cham: Springer International Publishing, 2017. Available: https://doi.org/10.1007/978-3-319-56339-8

[50] I. Mergel, "Opening Government: Designing Open Innovation Processes to Collaborate With External Problem Solvers," Soc. Sci. Comput. Rev., vol. 33, no. 5, pp. 599-612, 2015. Available: https://doi.org/10.1177/0894439314560851

[51] P. Johannesson and E. Perjons, An Introduction to Design Science. Cham: Springer, 2014. Available: https://doi.org/10.1007/978-3-319-10632-8

[52] K. Peffers, T. Tuunanen, M. A. Rothenberger, and A. S. Chatterjee, "A Design Science Research Methodology for Information Systems Research," J. Manag. Inf. Syst., vol. 24, no. 3, pp. 45-77, 2008. Available: https://doi.org/10.2753/MIS0742-1222240302

[53] M. Saunders, P. Lewis, and A. Thornhill, Research Methods for Business Students, 9th ed. Harlow: Pearson Education, 2009.

[54] A. Bryman, "Integrating quantitative and qualitative research: How is it done?," Qual. Res., vol. 6, no. 1, pp. 97-113, 2006. Available: https://doi.org/10.1177/1468794106058877

[55] D. Coghlan and T. Brannick, Doing action research in your own organization, 4th ed. London: Sage Publications, 2014.

[56] Z. Elsahn, L. Callagher, K. Husted, S. Korber, and F. Siedlok, "Are rigor and transparency enough? Review and future directions for case studies in technology and innovation Management," $R$ D Manag., vol. 50, no. 3, pp. 309-328, 2020. Available: https://doi.org/10.1111/radm.12412 
[57] R. K. Yin, Case Study Research - Design and Methods, 2nd ed. Thousand Oaks: SAGE Publications, 1994.

[58] S. Y. Perng, R. Kitchin, and D. Mac Donncha, "Hackathons, entrepreneurial life and the making of smart cities," Geoforum, vol. 97, pp. 189-197, 2018. Available: https://doi.org/10.1016/j.geoforum.2018.08.024

[59] M. P. Lyndon et al., "Hacking Hackathons: Preparing the next generation for the multidisciplinary world of healthcare technology," Int. J. Med. Inform., vol. 112, pp. 1-5, 2018. Available: https://doi.org/10.1016/j.ijmedinf.2017.12.020

[60] J. S. Bell, F. E. Murray, and E. L. Davies, “An investigation of the features facilitating effective collaboration between public health experts and data scientists at a hackathon," Public Health, vol. 173, no. 2019, pp. 120125, 2019. Available: https://doi.org/10.1016/j.puhe.2019.05.007

[61] P. Leclair, “Hackathons: A Jump Start for Innovation,” Public Manag., vol. 44, no. 1, pp. 12-14, 2015.

[62] S. Marx and M. Klotz, "Open Innovation in Interorganisational Cooperation: Case of Hackathons in Museums," Buisness, Economics and Science, pp. 148-153, 2020.

[63] K. N. Hsieh and J. Tidd, "Open versus closed new service development: The influences of project novelty," Technovation, vol. 32, no. 11, pp. 600-608, 2012. Available: https://doi.org/10.1016/j.technovation.2012.07.002

[64] G. I. Susman and R. D. Evered, "An Assessment of the Scientific Merits of Action Research," Adm. Sci. Q., vol. 23, no. 4, pp. 582-603, 1978. Available: https://doi.org/10.2307/2392581

[65] P. Ziek and J. D. Anderson, “Communication, dialogue and project management," Int. J. Manag. Proj. Bus., vol. 8, no. 4, pp. 788-803, 2015. Available: https://doi.org/10.1108/IJMPB-04-2014-0034

[66] J. F. Moore, "Predators and Prey," Harvard Business Review, no. May-June. pp. 75-86, 1993.

[67] P. Turkama, "The Future Focus for Open Innovation," Open Innovation 2.0 Yearbook 2017-2018, Luxembourg: European Union, 2018, pp. 93-98.

[68] V. van de Vrande, J. P. J. de Jong, W. Vanhaverbeke, and M. de Rochemont, "Open innovation in SMEs: Trends, motives and management challenges," Technovation, vol. 29, no. 6-7, pp. 423-437, 2009. Available: https://doi.org/10.1016/j.technovation.2008.10.001

[69] F. Gama, "Managing collaborative ideation: the role of formal and informal appropriability mechanisms," Int. Entrep. Manag. J., vol. 15, no. 1, pp. 97-118, 2019. Available: https://doi.org/10.1007/s11365-018-0544-1

[70] S. Schulz, "Grundlagen der medizinischen Statistik für Gesundheitsberufe," Gesundheitswissenschaften, R. Haring, Ed. Berlin, Heidelberg: Springer, pp. 61-75, 2019 (in German). Available: https://doi.org/10.1007/978-3-662-58314-2_7

[71] Universität Zürich, "Mann-Whitney-U-Test," Methodenberatung, 2020. Available: https://www.methodenberatung.uzh.ch/de/datenanalyse_spss/unterschiede/zentral/mann.html

[72] J. Cohen, “A power primer," Psychol. Bull., vol. 112, no. 1, pp. 155-159, 1992. Available: https://doi.org/10.1037/0033-2909.112.1.155

[73] H. Chesbrough and S. Brunswicker, "Managing Open Innovation in Large Firms," Stuttgart, 2013.

[74] S. Marx, "Project management practice in interreg projects: Reflective analysis and recommendations," SIMAT Arbeitspapiere, vol. 09-17-031, M. Klotz, Ed. Stralsund: Hochschule Stralsund, Stralsund Information Management Team (SIMAT), pp. 1-45, 2017.

[75] P. M. Bosch-Sijtsema and T. J. B. M. Postma, "Governance factors enabling knowledge transfer in interorganisational development projects," Technol. Anal. Strateg. Manag., vol. 22, no. 5, pp. 593-608, Jul. 2010. Available: https://doi.org/10.1080/09537325.2010.488064 